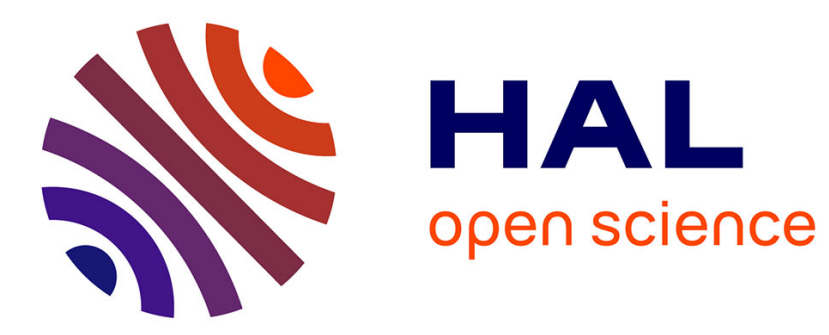

\title{
as a bioindicator for organotin contamination in coastal environments
}

\author{
Aricelso Maia Limaverde, Angela de L. Rebello Wagener, Marcos A. \\ Fernandez, Arthur de L. Scofield, Ricardo Coutinho
}

\section{To cite this version:}

Aricelso Maia Limaverde, Angela de L. Rebello Wagener, Marcos A. Fernandez, Arthur de L. Scofield, Ricardo Coutinho. as a bioindicator for organotin contamination in coastal environments. Marine Environmental Research, 2007, 64 (3), pp.384. 10.1016/j.marenvres.2007.03.001 . hal-00562973

\section{HAL Id: hal-00562973 https://hal.science/hal-00562973}

Submitted on 4 Feb 2011

HAL is a multi-disciplinary open access archive for the deposit and dissemination of scientific research documents, whether they are published or not. The documents may come from teaching and research institutions in France or abroad, or from public or private research centers.
L'archive ouverte pluridisciplinaire HAL, est destinée au dépôt et à la diffusion de documents scientifiques de niveau recherche, publiés ou non, émanant des établissements d'enseignement et de recherche français ou étrangers, des laboratoires publics ou privés. 


\section{Accepted Manuscript}

Stramonita haemastoma as a bioindicator for organotin contamination in coastal environments

Aricelso Maia Limaverde, Angela de L. Rebello Wagener, Marcos A.

Fernandez, Arthur de L. Scofield, Ricardo Coutinho

PII:

S0141-1136(07)00042-6

DOI:

10.1016/j.marenvres.2007.03.001

Reference:

MERE 3109

To appear in:

Marine Environmental Research

Received Date:

28 October 2005

Revised Date:

3 March 2007

Accepted Date:

9 March 2007

Please cite this article as: Limaverde, A.M., de L. Rebello Wagener, A., Fernandez, M.A., de L. Scofield, A., Coutinho, R., Stramonita haemastoma as a bioindicator for organotin contamination in coastal environments, Marine Environmental Research (2007), doi: 10.1016/j.marenvres.2007.03.001

This is a PDF file of an unedited manuscript that has been accepted for publication. As a service to our customers we are providing this early version of the manuscript. The manuscript will undergo copyediting, typesetting, and review of the resulting proof before it is published in its final form. Please note that during the production process errors may be discovered which could affect the content, and all legal disclaimers that apply to the journal pertain. 


\title{
Stramonita haemastoma as a bioindicator for organotin contamination in coastal environments
}

Aricelso Maia Limaverde ${ }^{1}$, Angela de L. Rebello Wagener ${ }^{1 *}$, Marcos A. Fernandez ${ }^{2}$, Arthur de L. Scofield ${ }^{1}$, Ricardo Coutinho ${ }^{3}$.

${ }^{1}$ Departamento de Química, Pontifícia Universidade Católica do Rio de Janeiro, 22453-900 Rio de Janeiro, Brazil. (*) Corresponding Author, angela@ rdc.puc-rio.br

${ }^{2}$ Departamento de Oceanografia, Universidade do Estado do Rio de Janeiro, 20250-013 Rio de Janeiro, Brazil.

${ }^{3}$ Departamento de Oceanografia, Instituto de Estudos do Mar Almirante Paulo Moreira, Arraial do Cabo, 28930-000 Rio de Janeiro, Brazil.

\begin{abstract}
Stramonita haemastoma was investigated as a suitable bioindicator of TBT and TPhT contamination in the tropical Atlantic Ocean by: 1. Imposex induction in healthy females after inoculation with TBT and TphT in the laboratory; and 2. Determining incidence of imposex in S. haemastoma collected from areas with various levels of tributyltin (TBT) and triphenyl tin (TphT) and determining the concentrations of these chemical in its tissues and that of its prey , the mussell Perna pernas. Imposex intensities and organotin concentrations in tissues showed good correlation, indicating S. haemastoma as a reliable bioindicator of TBT and TPhT contamination in coastal waters. Body burden threshold of TBT and TPhT for imposex induction was estimated to be $10-20 \mathrm{ng}^{-\mathrm{g}^{-1}}$.

Keywords: organotins, Stramonita (Thais) haemastoma, bioassay, Guanabara Bay
\end{abstract}




\section{Introduction}

Organotins (OT) are man-made organometallic compounds widely used as biocides, mainly as antifouling paints on ship hulls. TBT and TPhT (triphenyltin) liberated from the hulls in contact with seawater have been shown to be very toxic to the marine biota (Hoch, 2001;

Champ, 2000). The most characteristic sub-lethal effect of organotins is hormonal disruption in gastropods, leading to the imposition of male sexual attributes in the females, i.e., imposex (Gibbs \& Bryan, 1986; Horiguchi, Shiraishi, Shimizu \& Morita , 1997; Depledge \& Billinghurst, 1999). Imposex, has been observed in several areas of the globe where OT contamination is present (Mathiessen \& Gibbs, 1998). The neogastropod Stramonita haemastoma is a muricid, closely related anatomically to other species of the genus Thais. This genus is widespread in tropical and temperate waters, including the Mediterranean (Rilov, Gasith, Evans \& Benayahu, 2000), North America, the Caribbean and South America (Rios, 1994), Australia and Asia (Stewart, De Mora, Jones \& Miller, 1992; Tan, 1997; Bech, 2002a), living even in cool waters in Korea and Japan (Horiguchi, Shiraishi, Shimizu \& Morita, 1994; Shin , Kahng, Hong, Kim, Kim \& Shim, 2000). The incidence and intensity of imposex in S. haemastoma varies inversely with the distance from OT sources, as for instance, harbors, marinas and shipyards (Spence, Hawkins \& Santos, 1990; Castro, Cascón, \& Fernandez, 2000; Rilov, Gasith, Evans \& Benayahu,, 2000; Fernandez, Limaverde, Castro, Terra \& Wagener, 2002; Fernandez, Wagener, Limaverde, Scofield, Pinheiro \& Rodrigues, 2005). Among species of the Thais genus, imposex was shown to occur in T. orbita (Stewart et al, 1992), T. clavigera (Horiguchi et al, 1994; Tan, 1997; Blackmore, 2000; Shin et al, 2000; Hung, Hsu, Mang \& Chuang, 2001), T. bronni (Horiguchi et al, 1994), T. bitubercularis (Tan, 1997; Bech, 2002a), T. distinguenda (Tan, 1997; Bech, 2002a), T. jubilacea (Tan, 1997), and T. rufotincta (Bech, 2002a). A few authors used organotins in bioassays to induce imposex in $\boldsymbol{T}$. clavigera: Horiguchi et al (1997) used injection of the toxicants, while Liu \& Suen (1996) tested direct exposure to the toxicant in water. Bech (2002b) tested transplantation of $\boldsymbol{T}$. distinguenda from non-contaminated to contaminated sites 
coupled to body burden chemical evaluation. All studies gave positive results for imposex induction by organotins.

In Brazil, very little is known about the presence and threats imposed by organotins in coastal environments. Fernandez et al (2005) and Almeida, Wagener, Maia \& Miekeley (2004) found high concentrations of TBT in sediments of Guanabara Bay, in Rio de Janeiro, and reported that TBT may be persistent in the anoxic sediments of the bay. Godoi, Montone \& Santiago-Silva (2003) also reported high concentrations in sediments from the Santos Bay, where boat and ship traffic is very intense. As for biological studies, Fernandez, Nogueira, Miyamoto \& Wagener. (1997), Magalhães, Struchi \& Asbahr, (1997) and Castro et al (2000) reported the occurrence of imposex in Stramonita haemastoma in Rio de Janeiro, Santos and Recife. Imposex was also found in Stramonita Rustica in the Northeastern coast of Brazil (Camillo Jr, Quadros, Castro \& Fernandez, 2004; Castro, Meirelles, Cascón \& Fernandez, 2004), however, in most cited studies the cause of such an alteration has not been proven to be TBT by correlating, for instance, the anomaly intensity with chemical body burden.

Brazil, as most Latin American countries, does not regulate the use of organotins on vessels.

An International Convention under IMO authority is under way to globally ban the use of organotins as antifouling agents. However, these substances will be present in the marine environment long after banning, either released from ship hulls still carrying these substances, or from anoxic sediments where TBT may show a half-live of several years (Dowson, Bubb \& Lester, 1996; Stewart \& Thompson, 1997; Alzieu, 1998). Enforcing such a convention will imply monitoring environmental conditions, a process that may be tedious and expensive, especially for developing countries such as Brazil, with more than 7,000 $\mathrm{km}$ of coast.

The use of a reliable bioindicator as a tool for screening hotspots is a viable option to the expensive chemical analysis of samples from every site suspected of contamination (Axiak Vella, Micallef, Chircop \& Mintoff, 2003, Fernandez et al, 2005). Having this in mind the present work 
tests for a cause-and-effect relationship between TBT and TPhT exposure and the development of imposex in Stramonita haemastoma. Two approaches were taken: (1) a laboratory bioassay, or dosing experimenet; and (2) a field investigation of imposex coupled to organotin determination in the gastropod as well as in its natural prey (Perna perna) in Guanabara Bay. Our goal was to validate the use of this widespread gastropod species, and of the mussel Perna perna, as sentinels for organotin contamination in coastal environments in Brazil, and in other areas where they occur.

\section{Methods}

\section{Sampling}

For the bioassay, gastropods, and mussels used as feed, were collected in January 2001, from the Pontal do Atalaia in Arraial do Cabo, Rio de Janeiro. This is a pristine area where Stramonita populations were healthy and showed no evidences of imposex (Ribeiro, 2002).

For the survey in Guanabara Bay samples of Stramonita haemastoma and Perna perna were collected in September, 2000 and in October-December, 2001, from rocky substrates in sites at different distances from known sources (see Figure 1) of organotins, so as to obtain an imposex gradient in the field. From each site a minimum of 20 individuals were collected (Ellis \& Pattisina, 1990). Sexual maturity of the gastropods was inferred from shell size that was, in general, close to $40 \mathrm{~mm}$, and the presence of marked ribs at the shell edge, near the operculum (Minchin \& Davies, 1999; Ellis \& Pattisina, 1990). During transportation to the laboratory all organisms were kept in aquaria equipped with an air pump.

\section{Bioassay}

From the total of 400 collected individuals measuring $40 \pm 5 \mathrm{~mm}$ of shell length (measures were taken with vernier calipers), 25 were randomly picked and examined for confirmation that the sampled population was imposex free. The assay was performed in 8 aquaria containing 42 gastropods and 10 mussels each. The aquaria were filled with $35 \mathrm{~L}$ of 
seawater, collected from the sampling site given above, and equipped with air pumps, and activated charcoal filters. Five days were given for adaptation of the organisms to the new conditions prior to starting the inoculations. Two of the 8 aquaria were used as controls. Animals from one of the control batches were inoculated with ethanol (Merck, P.A.), the solvent used for diluting TBT and TPhT standards. The remaining aquaria were divided in two groups of three aquaria; the first group was used for inoculation of the organisms with increasing concentrations of TBT (aquaria TBT-1, TBT-2, TBT-3), and the second group was used for inoculation of TPhT aquaria TPhT-1, TPhT-2, TPhT-30). To ensure better control of the desired dose, the relation between shell length (SL) and fresh weight of soft parts (FW) was tested in a separate batch of organisms $\left(\mathrm{SL}_{(\mathrm{mm})}=3,46 \times \mathrm{FW}_{(\mathrm{g})}+29,97 ; \mathrm{r}=0,725\right)$. This relation was thereafter used to estimate the animal mass from the shell length (for example, an organism of $40 \mathrm{~mm}$ shell length has an average weight of $2.9 \mathrm{~g}$ ). Based on the work of Horiguchi et al (1994) the applied dose was of the order of 10-20 ng. $\mathrm{g}^{-1}$. Solutions of tributyltin chloride $96 \%$ and triphenyltin chloride 95\% (Aldrich Chem. Co.) were then prepared by diluting the standards with ethanol (Merck, P.A.). Inoculation was performed by injecting $1 \mu \mathrm{L}$ (containing the following amounts of organotin as Sn: TBT-1 = 14.9 ng; TBT-2 $=29.9$ ng; TBT-3 = 59.6 ng; TPhT-1 = 12.9 ng; TPhT-2 $=25.9 \mathrm{ng} ;$ and TPhT $-3=51.8 \mathrm{ng}$ ) of the diluted solution in the animal foot with the aid of a $5 \mu \mathrm{L}$ chromatographic syringe. An air-solution-air sandwich was used to ensure that the desired volume was fully injected. Elapsed 14 days (Group1) from inoculation, 15 organisms were removed from each aquarium for determination of the imposex frequency and intensity. The same evaluation was applied to the remaining organisms 28 days after the inoculation (Group 2). A previous transplantation test had shown that this time was sufficient for imposex development in this species (Ribeiro, 2002).

During the 4 weeks of the bioassay duration, water in the aquaria was exchanged weekly. Temperature and salinity were always kept at the initial conditions $\left(20^{\circ} \mathrm{C}\right.$ and $34.5 \mathrm{~g} \mathrm{~kg}^{-1}$, respectively). Living mussels were also weekly replaced by freshly harvested animals, and those 
by chance dying during the experiment were immediately removed from the aquaria.

\section{Field Gradient Study}

Animals were sampled at five sites in Guanabara Bay (Figure 1) previously studied for imposex intensity by Fernandez (2001). Sampling stations were selected as to possibly provide animals with a broad range of imposex intensity (from an expected maximum in the near of the Rio de Janeiro Yacht Club, in Urca wave breaker, to a minimum in the less impacted area of the Cagarras Islands, located outside the bay). From each site at least 20 individuals were collected (Ellis \& Pattisina, 1990). The sexual maturity of the gastropods was inferred from the shell size $(40.0 \pm 5.0 \mathrm{~mm})$, and the presence of marked ribs at the shell edge, near the operculum (Ellis \& Pattisina, 1990; Minchin \& Davies, 1999). During transportation to the laboratory all organisms were kept in air-pump-equipped aquaria.

Imposex intensity was determined in the gastropods from each station. Thereafter, these animals, along with a sample of 20 mussels Perna perna per station, were separated for chemical analysis.

\section{Imposex intensity evaluation}

Sex of the animals was determined by the presence of the prostate gland in males, and the albumen, sperm-ingesting and capsule gland in females (Gibbs \& Bryan, 1987, 1994; Horiguchi et al, 1994). Penis length in males and in imposexed females was also measured with calipers (Axiak et al, 1995), and vas deferens development was observed under a binocular microscope.

Imposex response in the populations was evaluated by using the RPLI (relative penis length index), RPSI (relative penis size index) and VDSI (vas deferens sequence index), according to the procedures given under Gibbs \& Brian, 1986; Gibbs, Bryan, Pascoe \& Burt, 1987; Fioroni, Oehlmann \& Stroben, 1991; Stroben, Schulte-Oehlmann, Fioroni \& Oehlmann, 1995. This last index was determined using a six-stage scale similar to the classic Gibbs scale for Nucella lapillus (Gibbs \& Bryan, 1994) adapted for Stramonita haemastoma by Fernandez et al. (2002). In this scale, grade 0 is attributed to normal females. Grade I includes females presenting 
a small hump or pre-penis behind the right tentacle. In Grade II, a small penis is visible. In grade III, the penis is bigger, and an incomplete vas deferens could be observed in the palial cavity floor. In grade IV, the vas deferens is complete and female penis reach a size greater than half of the male's mean size. Grade V is characterized by vulva blockage and Grade VI by aborted egg mass in the capsule gland. After narcotization with a $7 \% \mathrm{MgCl}_{2}$ in a $1: 1$ solution of distilled water:local seawater (Huet et al, 1995) shells were crushed using a small vice. Narcotization was required to obtain precise measurements of penis size, since the unarcotized organism retracts after shell removal rendering manipulation and anatomic examination very difficult.

\section{Sample pre-treatment for chemical analysis}

Separate composite samples of female and male gastropods from each station were prepared for chemical analysis. Soft tissues selected for chemical analysis were homogenized in an Ultra Turrax and duplicate sub-samples of each homogenate were stored at $-20^{\circ} \mathrm{C}$ in clean glass vessels until analysis. Mussel's soft parts were removed from the shells with the aid of a stainless steel blade. A pooled sample (20 individuals) from each station was homogenized in an Ultra Turrax. Duplicate sub-samples were stored at $-20^{\circ} \mathrm{C}$ in clean glass containers until analysis. Similarly, pooled samples of males and females from each aquarium of the bioassay were prepared and analyzed in duplicate. Gastropods were fed during the bioassays with mussels collected weekly; therefore, organotins were analyzed in sub samples of each batch of harvested mussels.

\section{Analytical Procedure}

Analytical protocol was based on Bayona, Fernandez, Porte, Tolosa, Valls \& Albaiges (1991) and adapted as described in Fernandez et al. (2005) to the determination by gas chromatography with pulsed flame photometric detection GC/PFPD. The analytical procedure including extraction, clean-up, derivatization and GC/MS determination is described in length in Limaverde (2001). In brief, after spiking $2 \mathrm{~g}$ of tissue homogenate with tripropyltinchloride (TPrTCl 98\%, Merck) and tricyclohexyltinchloride (TcyTCl 97\%, Aldrich), samples were treated 
with methanol in $\mathrm{HCl}$ and extracted with tropolone solution in 3:2 ethyl ether/hexane and sonication. Derivatization proceeded with $\mathrm{PeMgBr}$ in diethyl ether under $\mathrm{N}_{2}$ atmosphere. Cleanup was done in glass columns filled with activated silica and anhydrous $\mathrm{Na}_{2} \mathrm{SO}_{4}$. After elution with ethyl ether in hexane and volume reduction under $\mathrm{N}_{2}$ stream, tetrabutyltin was added as internal standard.

A Varian 3600CX gas chromatograph fitted with an 8200 auto sampler, a pulsed photometric detector (Varian) and a DB-17 (50\%-phenyl-methylpolysiloxane) fused silica column (J\&W Scientific) were used. The detailed chromatographic conditions are given under Fernandez et al (2005). The determinations were made in triplicate. Quantification was performed by internal standard procedure, using TeBT added after derivatization. Procedural blanks were carried out for every batch of samples.

The analytical procedure was validated by analyzing the reference material NIES-11 (National Institute for Environmental Studies- Environmental Agency of Japan) certified for TBT. The values found for TBT $\left(512 \pm 58 \mathrm{ng} \cdot \mathrm{g}^{-1}\right.$ as $\left.\mathrm{Sn} ; \mathrm{n}=6\right)$ and TPHT $\left(1384 \pm 260 \mathrm{ng} \cdot \mathrm{g}^{-1}\right.$ as Sn; $n=6)$ are in good agreement with the certified value for TBT $\left(475 \pm 36 \mathrm{ng} \cdot \mathrm{g}^{-1} \mathrm{dw}\right.$ as Sn $)$ and the suggested value for TPHT (1942 $\left.\mathrm{ng}^{-\mathrm{g}^{-1}}\right)$, respectively. The calibration curves gave correlation coefficients ( $\mathrm{n}=6)$ of: 0,999 (TBT, DBT, MBT, TCyT), 0,986 (TPhT and DPhT), 0,979 (MPhT) and 0,995 (TeBT). The concentration of butyltins and phenyltins were corrected for recovery of TPrT $\left(73 \pm 5 \mathrm{ng} \cdot \mathrm{g}^{-1}\right)$. The losses involved in the overall process were estimated by analyzing a sample low in organotins, spiked with a mixture of the standards (TPrT, TBT, DBT, MBT, TPhT, DPhT, MPhT and TCyT) of known concentrations. Equilibration was allowed for 2 hours before extraction. The average value found was $75 \pm 12 \%$ of the initial concentration (TBT gave 91 $\pm 18 \%$, and the lowest value, not included in the average, was of $60 \pm 2 \%$ for MPhT). Mean relative standard deviations for $\mathrm{n}=5$ were: $12.2 \%$ (TPrT), $3.5 \%$ (TBT), $15.0 \%$ (DBT), $14.8 \%$ (MBT), 27.4\% (TPhT), and 36\% (DPhT). Detection limits given as [Sn] for the various organotins are: $\mathrm{TBT}=0.39 \mathrm{pg} ; \mathrm{DBT}=0.66 \mathrm{pg} ; \mathrm{MBT}=0,96 \mathrm{pg} ; \mathrm{TPhT}=0.90 \mathrm{pg} ; \mathrm{DPhT}=$ 
$0.72 \mathrm{pg}$.

\section{Results and Discussion}

Table 1 shows the results for the bioassay. Because of the small penis development in imposex females, RPLI and RPSI were not calculated, except for females harvested 28 days after TBT inoculation, which displayed penis of more than $1 \mathrm{~mm}$ (RPLI $=17,1$; total number of females was equal to 7 from which 5 (71\%) showed imposex). The average penis length found in females 28 days after inoculation of $20 \mathrm{ng} \cdot \mathrm{g}^{-1}$ TBT (TBT-3) was $1.5 \pm 0.9 \mathrm{~mm}$. Horiguchi et al (1994) and Bech et al (2002b) also found for gastropods of the same genus as S. haemastoma that TBT concentrations of $10-20 \mathrm{ng} . \mathrm{g}^{-1}$ of fresh tissue induced development of imposex. Sampling 14 days after inoculation of TPhT was not carried out because of the high mortality observed. In this case, all survivals were harvested 28 days after inoculation, and among those only one female presented a measurable penis size $(2 \mathrm{~mm}) . \quad$ As for the VDSI, no significant differences were observed among organisms 14 days after inoculation with different TBT doses; all altered organisms were classified as in level 1 of the applied VDSI scale. Two animals in the control group, inoculated with ethanol, developed imposex. A good correlation was found between frequency of imposex incidence and inoculated doses (see Figure 2).

The groups of organisms sampled 28 days after inoculation with $59.6 \mathrm{ng}$ of TBT (as $\mathrm{Sn}$ ) and $51.8 \mathrm{ng}$ of TPhT (as Sn), respectively, had significant VDSI levels: 2.3 ( $\mathrm{n}=6$ ) for TBT inoculation, and $1.4(\mathrm{n}=5)$ for TPhT while the control group was imposex free. The $\mathrm{X}^{2}$ test and contingency tables were used to check for possible independence of $\mathrm{F}$ (healthy females) and I (imposexed females) factors from organotins inoculation dose. For TBT the test was applied first separately to the results for 14 (Group 1) and 28 (Group 2) days of experimentation, and then to the entire data set. The dependency relation found between F/I and the injected dose for Group 1 $\left(\mathrm{x}_{\mathrm{o}}=12.72 ; \mathrm{x}=9.23\right.$, d.o.f. $\left.=5, \mathrm{p}<0.05\right)$ is more evident for Group 2 data since the independence hypothesis was rejected with a value well above the rejection threshold $\left(\mathrm{x}_{\mathrm{o}}=\right.$ 
35.81; $\mathrm{x}=9.23$, d.o.f. $=5, \mathrm{p}<0.001)$. Similar relations were obtained for TPhT data in Group

2.

Chemical analysis revealed DBT $\left(7.38 \pm 2.53 \mathrm{ng} \mathrm{g}^{-1} \mathrm{ww}\right.$ as $\mathrm{Sn}$ for females and $13.70 \pm$ $2.06 \mathrm{ng} \mathrm{g}^{-1} \mathrm{ww}$ as Sn for males) contamination in the gastropods freshly harvested from the sampling site, and the presence of DBT (5.20 to $6.94 \mathrm{ng} \cdot \mathrm{g}^{-1}$ ww as Sn) and MBT (0.54 to $1.05 \mathrm{ng}$ $\mathrm{g}^{-1} \mathrm{ww}$ as $\mathrm{Sn}$ ) in the mussels. In the control batches, DBT and MBT concentrations increased over the 28 days of experiment, resulting in a DBT background value (as Sn) of $20.4 \pm 0.6{\mathrm{ng} . \mathrm{g}^{-1}}^{-1}$ in the gastropods. This is an indication that seawater from the area, taken as pristine, contained traces of organotins, possibly derived from eventual navigation activities (pleasure and fishing boats). Although the contamination source for DBT was not clearly identified here, based on the observations of Horiguchi et al (1997) and in the present observations it can be assumed that the background DBT concentration in the gastropods played no role in the development of imposex. The presence of MBT and MPT concentration in excess of the background in females after 28 days of inoculation is evidence of parent compound metabolism.

Table 2 shows organotin concentrations in the animals of the bioassay, and Figure 3 displays the mass balance obtained by using the inoculated dose, the background concentration, and the measured body burden after 14 and 28 days of inoculation. This balance provides an estimate of the average organotin fraction accumulated in the organism. TPhT concentrations in females was $30-40 \%$ higher than for TBT, and evidently the accumulation in males is remarkably smaller than in females, especially for TBT, suggesting a more effective biotransformation mechanism in males. The generally higher TPhT persistence in tissues, also observed by Horiguchi, Shiraishi, Shimizu, Yamazaki \& Morita (1995), suggests a slower metabolization of this compound in this species.

The field studies showed that organotin concentrations in gastropods (see Table 3) from Leme, Cagarras Islands, Vermelha Beach, Cotumduba and Urca are of the same order of those reported for gastropod of the same genus from other contaminated areas (Horiguchi et al, 1995). 
A single study by of Rilov et al (2000) along the coast of Israel reports imposex development as well as organotin concentrations in $\mathbf{S}$. haemastoma. TBT, DBT and MBT concentrations of $447.7 \mathrm{ng} . \mathrm{g}^{-1}, 913.6 \mathrm{ng} \cdot \mathrm{g}^{-1}$ and $111.3 \mathrm{ng} \cdot \mathrm{g}^{-1}$, respectively, were found in animals from Herzelia marina, heavily polluted by organotins. Mean VDSI was 4 and some sterile females where identified. At Ha Bonin, a natural reserve and reference area, concentrations were 18.9 ng. $\mathrm{g}^{-1}$ TBT, 51.2 ng.g ${ }^{-1}$ DBT and 12.2 ng.g ${ }^{-1}$ MBT, while $25 \%$ of females displayed imposex and RPSI was of 0.1. At Vermelha beach, some $4-5 \mathrm{~km}$ away from the main organotin sources in Guanabara Bay, TBT, DBT, MBT and TPhT average concentrations were $20.3 \mathrm{ng} . \mathrm{g}^{-1}, 36.9 \mathrm{ng} . \mathrm{g}^{-1}$, 4,6 ng. $\mathrm{g}^{-1}$ and $7.45 \mathrm{ng} \cdot \mathrm{g}^{-1}$, respectively. Mean VDSI of 3 and RPLI of 30.7 for S.haemastoma in Vermelha Beach indicated a more severe response at comparable body burdens. The presence of TPhT, which also induces imposex in this species, may account for the apparent higher sensitivity of animals in Vermelha Beach.

As for the mussels, butyltins were at concentrations comparable with those reported for mussels of the same genus (Perna viridis, L.) from contaminated areas of Thailand (KanAtireklap, Tanabe, Sanguansin, Tabucanon \& Hungspreugs 1997), for Mytilus trossulus from Vancouver Harbour (Horiguchi et al, 2003), and for mussels from Danish coastal waters (NERI 2000 apud Strand \& Jacobsen, 2005). Concentrations in the gastropod were, in general, in the following order: $\mathrm{DBT}>\mathrm{TBT}>\mathrm{MBT}$. The same order was observed in the mussel tissues, except for animals from Urca where $\mathrm{TBT}>\mathrm{DBT}>\mathrm{MBT}$. TPhT was the most important phenyl species in both cases.

Berg, Arnold Müller, Mühlemann \& Schwarzenbach (2001) and Langston \& Pope (1995) showed that TBT sorption on particulate organic matter is fast and reversible; therefore besides TBT in the dissolved phase, particulate organotins are also potentially available to filter feeders (De Mora, 1996). From all observed sites, Urca, located in a highly eutrophic embayment and in the near of an important leisure boat anchoring area, is the most likely to contain a significant fraction of organotins adsorbed on organic particles. These set of conditions may explain the 
high absolute and relative TBT concentrations in the organisms from this site.

Bryan et al (1989) estimated that in carnivorous gastropod organotins body burden seem to result from equal contributions from diet and the surrounding environment. The bioconcentration (BC; uptake from water or particulate phase via body surface) in mussels Mytilus edulis reported by Laughlin et al (1986) is of the order of 5000 while the biomagnification factor (BM; through algae ingestion) was equal to 2 . By using such a $\mathrm{BC}$ it is possible to roughly estimate that in the sampled sites butyltin concentration in the water column (assuming that biomagnification is of lesser importance) ranged from $1.5 \mathrm{ng} \mathrm{\textrm {L } ^ { - 1 }}$ in Arraial do Cabo to $33 \mathrm{ng} \mathrm{L}^{-1}$ in Urca. Such conceentrations are of special concern since detrimental effects of TBT on plankton and oysters have been reported at the concentration range from 0.5 to 50 ng. $L^{-1}$ (Alzieu, 1996). In the study by Stroben, Schulte-Oehlmann, Fioroni \& Oehlmann, (1995), relating imposex level in gastropods to TBT concentrations in water, sterility in Nucella lapillus, the only muricid tested that showed this phenomenon, commenced at $4-6$ ng. $\mathrm{L}^{-1} \mathrm{TBT}$ and was widespread in populations exposed to 20 - $30 \mathrm{ng} \mathrm{L}^{-1}$ TBT levels. These levels are similar to the estimate in Urca, where females of S.haemastoma could not be found. Because imposex development in this gastropod species can cause female sterility, which leads to profound alteration in populations, the absence of females in Urca seems to concur with the estimated level of 33 ng.L $\mathrm{L}^{-1} \mathrm{TBT}$ in water.

Some authors have studied the biomagnification of organotins in food webs (Laughlin, French \& Guard, 1986; Strand \& Jacobsen, 2005). Mensink, Boon, ten Hallers-Tjabbes, van Hattun \& Koeman, (1997) calculated for a North Sea whelk a BM of 8 in relation to Mytilus edulis, and TBT concentrations in snails lower than in mussel by a factor of 7. Stäb, Traas, Stroomberg van Kesteren, Leonards, van Hattum et al (1996) also report no biomagnification in the food web of fresh water systems in Netherlands. In the present work, BM $(\mathrm{BM}=$ $[\mathrm{OT}]_{\text {gastr. }} /[\mathrm{OT}]_{\text {mussel }}, \mathrm{OT}=$ organotins $)$ values for TBT ranged from 0.5 to $2.7(\mathrm{n}=6$ observed sites); for DBT the range was from 0.9 to 1.6 ; for MBT 1.2-3.5; and for TPhT 1.9 to 7.6 ( $\mathrm{n}=4$ 
sampling sites). Data were not normalized to lipid content because of the higher affinity of the studied compounds to proteins. For the butyltins the linear plot $\left([\mathrm{BT}]_{\text {gastropod }}=13.91+\right.$ $0.74[\mathrm{BT}]_{\text {mussels }} ; \mathrm{r}=0.953 ; \mathrm{p}=0.0009, \mathrm{BT}=$ butyltins) of concentrations in the gastropods versus concentrations in the mussels show that, in the low concentration range ([BT] $]_{\text {gastropod }} \leq 50 \mathrm{ng} \mathrm{g}^{-1}$ ww as $\mathrm{Sn}, \mathrm{BT}=$ butyltins), the calculated $\mathrm{BM}>1$, decreasing smoothly above this limiting concentration. If it is considered that biomagnification does not occur, this maybe the threshold value above which bioelimination mechanisms assume higher weight than bioaccumulation processes. The relatively high biomagnification for TPhT may imply that biotransformation mechanisms are less efficient for this compound.

TBT contribution to the BT body burden was of 37 to $64 \%$ in gastropods and of 37 to 67 $\%$ in mussels. There was no relation between the fraction of TBT in gastropods and in the mussels. Only mussels from Urca showed TBT at higher levels than DBT, indicating that recent inputs of antifouling overwhelm on going degradation processes.

The following pairs of data were tested for correlation: (1) VDSI levels and TBT concentration; (2) VDSI level and total butyltins; (3) VDSI level and the sum of all organotins. Because no females were found in Urca and there were no significant differences in organotin concentration between females and males, a tentative VDSI level for females, when existing in Urca, was obtained from the organotin concentration in males from this station using the linear equations $\left(y=0.004 x+0.145 ; r^{2}=0.885\right.$ for OTs versus VDSI, and $y=0.046 x+0.148 ; r^{2}=$ 0.903 for butyltins versus VDSI) obtained for data from all other sites. The obtained results of 6.2 (OTs) and 6.4 ( butyltins), included in the above correlation tests, may explain the absence of females there, since at these imposex levels possible lethal alterations are expected, as for instance blockage of the vulva and presence of dark decaying tissue in the capsule gland. Some populations in heavily impacted areas are composed mostly of males, because of selective female mortality (Gibbs \& Bryan, 1994). Figure 4 shows the plot of VDSI versus butyltins and the good fit of the bioassay values (VDSI $=2.3$ and butyltins $=28.2 \mathrm{ng} \cdot \mathrm{g}^{-1}, 28$ days after TBT 
inoculation) to the curve.

There was excellent correlation between the data obtained for mussels collected in the same sites and dates as the gastropods, and imposex levels in the later $(\mathrm{r}=0.934 ; \mathrm{p}<0.05)$. Because concentrations in mussels are closely related to that of contaminants in the water column, the above correlation suggests organotin induction of imposex in Stramonita haemastoma under local conditions in the observed sites.

\section{Conclusions}

The bioassay demonstrated that TBT and TPhT are capable of inducing imposex in $S$. haemastoma. This evidence coupled to the field studies demonstrate that this species is an adequate bioindicator of organotins contamination, either by means of monitoring the body burden of OTs or/ and determining imposex incidence. The inclusion of mussels in the field studies was useful as an indicator of the presence of organotins in the water column and demonstrated that this species is also functional in monitoring organotin contamination. Mussels can be useful in evaluating whether anomalies in gastropod population distribution (as in the case of Urca where only male gastropods were found) and linked to higher levels of organotin contamination in the environment. The results from the field studies allied to the bioassay confirmed the reliability of the VDSI scale proposed by Fernandez (2001) for S. haemastoma as demonstrated by the excellent correlation found between VDSI level and organotin concentrations in tissues.

The chemical analysis of animals used in the bioassay indicated metabolization and excretion of TBT and TPhT by females and males of $\boldsymbol{S}$. haemastoma with indications of a faster elimination in male gastropods.

As for concentrations of organotins in snails measured in the field study, those found for TBT in Vermelha Beach and in Urca are above the inoculated concentrations in the bioassay that caused imposex development. These areas evidently show contamination levels that pose a threat 
to molluscs and other organisms at the lower trophic levels, which appear to be at higher risk from exposure to such substances.

\section{Acknowledgments}

The authors are grateful for the financial support from the Rio de Janeiro Foundation for Science Funding (FAPERJ) and from the Federal Coordination for Tertiary Education (CAPES).

\section{References}

Almeida, A.C., Wagener, A. de L.R., Maia, C.B., \& Miekeley, N. (2004). Speciation of organotin compounds in sediment cores from Guanabara Bay, Rio de Janeiro (Brazil) by gas chromatography-pulsed flame photometric detection. Applied Organometallic Chemistry, 18, 694-704.

Alzieu, C. (1996) Biological effects of tributyltin on marine organisms. In S.J. de Mora (Ed), Tributyltin: Case study of an environmental Contaminant (pp.167-211). Cambridge: Cambridge University Press.

Alzieu, C. (1998). Tributyltin: case study of a chronic contaminant in the coastal environment. Ocean \& Coastal Management, 40, 23-36.

Axiak, V., Vella, A.J., Micallef, D., Chircop, P. E, \& Mintoff, B. (1995). Imposex in Hexaplex trunculus (Gastropoda: Muricidae): first results from biomonitoring of tributyltin contamination in the Mediterranean. Marine Biology, 121, 685-691.

Axiak, V., Micallef, D., Muscat, J., Vella, A., \& Mintoff, B. (2003). Imposex as a biomonitoring tool for marine pollution by tributyltin: some further observations. Environment International, $28,743-749$.

Bayona, J.M., Fernandez, P., Porte, C., Tolosa, I., Valls, M., \& Albaiges, J. (1991). Partitioning of urban wastewater organic microcontaminants among coastal compartments. Chemosphere, 23, 313-326. 
Bech, M., (2002a). A survey of imposex in muricids from 1996 and 2000 and identification of optimal indicators of tributyltin contamination along the east coast of Phuket Island, Thailand. Marine Pollution Bulletin, 44, 887-896.

Bech, M., Strand, J. \& Jacobsen, J.A. (2002b). Development of imposex and accumulation of butyltin in the tropical muricid Thais distinguenda transplanted to a TBT contamination site. Environmental Pollution, 119, 253-260.

Berg, M., Arnold, C.G., Müller, S.R., Mühlemann, J., \& Schwarzenbach, R.P. (2001). Sorption and desorption behavior of organotin compounds in sediment-pore water system. Environmental Science and Technology, 35, 3151-3157.

Blackmore, G., 2000. Imposex in Thais clavigera (neogastropoda) as na indicator of TBT (tributyltin) bioavailability in coastal waters of Hong Kong. Journal of Molluskan Studies, $66,1-8$.

Bryan, G.W. \& Gibbs, P.E., Hummerstone, L.G., \& Burt, G.R. (1989). Uptake and transformation of ${ }^{14} \mathrm{C}$-labelled tributyltin chloride by dog-whelk, Nucella lapillus: importance of absorption from diet. Marine Environment Research, 37 , 241-245.

Camillo Jr, E., Quadros, J.P., Castro, I.B., \& Fernandez, M.A. (2004). Imposex in Thais (Stramonita) rustica (Mollusca:Neogastropoda)(Lamark, 1822) as an indicator of organotin pollution in Maceio coast (Northeastern Brazil). Brazilian Journal of Oceanography, 52, 101105.

Castro, I.B., Cascón, H.M., \& Fernandez, M.A. (2000). Imposex in Thais heamastoma (Linnaeus, 1767)(Mollusca:Gastropoda) an indication of organotin contamination in the coast of Fortaleza-Ceara-Brazil. Arquivos de Ciências do Mar, 33, 51-56 (in Portuguese).

Castro, I.B, Meirelles, C.A., Cascón, H.M., \& Fernandez, M.A. (2004). Thais rustica (Lamark, 1822)(Mollusca:Gastropoda:Thaididae): bioindicator of contamination by organotin compounds in the coast of Natal city, Rio Grande do Norte state, Northeastern Brazil. Brazilian Journal of Oceanography, 52, 135-139. 
Champ, M.A. (2000). A review of organotin regulatory strategies, pending actions, related costs and benefits. The Science of the Total Environment, 258, 21-27.

De Mora, S.J. (1996). The tributyltin debate: ocean transportation versus seafood harvesting. In S.J. de Mora (Ed), Tributyltin: Case study of an environmental Contaminant (pp.1-20). Cambridge: Cambridge University Press.

Depledge, M.H., \& Billinghurst, Z. (1999). Ecological significance of endocrine disruption in marine invertebrates. Marine Pollution Bulletin, 39, 32-38.

Dowson, P.H., Bubb, J.M., \& Lester, J.N. (1996). Persistence and degradation pathways of tributyltin in freshwater and estuarine sediments. Estuarine, Coastal and Shelf Science, 42, $551-562$.

Ellis, D.V.E., \& Pattisina, L.A. (1990). Widespread neogastropod imposex: a biological indicator of global TBT contamination? Marine Pollution Bulletin, 21(n5), 248-253.

Fent, K. (1996). Ecotoxicology of organotin compounds. Critical Reviews in Toxicology, 26, 1117.

Fernandez, M.A., Nogueira, P.B., Miyamoto, P.T.H., \& Wagener. A.L.R. (1997). Imposex em Thais haemastoma no litoral do estado do Rio de Janeiro, Brasil. Um levantamento preliminar. In Anais X semana nacional de oceanografia, (pp. 406-408) Brazil:Itajai. (in portuguese)

Fernandez, M.A. (2001). Organotin compounds in Guanabara Bay (Rio de Janeiro): distribution and possible impacts. PhD thesis, Chemistry Departament, Pontifícia Universidade Católica do Rio de Janeiro, 202p (in Portuguese).

Fernandez, M.A., Limaverde, A.M., Castro, I.B., Terra, A.C., \& Wagener, A.L.R. (2002). Occurrence of imposex in Thais haemastoma: possible evidences of environmental contamination derived from organotin compounds in Rio de Janeiro and Fortaleza, Brazil. Cadernos de Saúde Pública, Reports in Public Health, 18 (n2), 463-476.

Fernandez, M.A.S., Wagener, A.L.R., Limaverde, A.M., Scofield, A.L, Pinheiro, F.M. \& 
Rodrigues, E. (2005). Imposex and surface sediment speciation: A combined approach to evaluate organotin contamination in Guanabara Bay, Rio de Janeiro, Brazil. Marine Environmental Research, 59, 435-452.

Fioroni, P., Oehlmann, J., \& Stroben, E. (1991). The pseudohermaphroditism of prosobanchs; morfological aspects. Zoollogischer Anzeiger, 286( n1/2), 1-26.

Gibbs, P.E., \& Bryan, G.W. (1986). Reproductive failure in populations of the dog-whelk Nucella lapillus, ceased by imposex induced by tributyltin from antifouling paints. Journal of the Marine Biological Association UK, 66, 767-777.

Gibbs, P.E., \& Bryan, G.W. (1987). TBT paints and demise of dog-whelk, Nucella lapillus (Gastropoda). In Proceedings, the oceans -an international workplace conference (Vol. 4, pp.1482-1487). Canada: Halifax.

Gibbs, P.E., Bryan, G.W., Pascoe, P.L., \& Burt, G.R. (1987). The use of dog-whelk Nucella lapilus, as an indicator of tributyltin (TBT) contamination. J. Marine Biol. Ass. U.K., 67 : 507-523.

Gibbs, P.E., \& Bryan, G.W. (1994). Biomonitoring of tributyltin pollution using the imposex response of neogastropod molluscs. In J. M. Kess \& Kramer (Eds.), Biomonitoring of coastal waters and estuaries (pp. 205-226). Boca Raton, FL: CRC Press.

Godoi, A.F.L., Montone, R.C., \& Santiago-Silva, M. (2003). Determination of tributyltin compounds in surface sediments from the São Paulo state coast (Brazil) by gas chromatographypulsed flame photometric detection. Journal of Chromatography A, 985, 205-210.

Hoch, M. (2001). Organotin compounds in the environment - an overview. Applied Geochemistry, $16,719-743$.

Horiguchi, T., Shiraishi, H., Shimizu, M. E., \& Morita, M. (1994). Imposex and organotin compounds in Thais clavigera e T. bronni in Japan. Journal of the Marine Biology Association of the UK, 74, 651-669.

Horiguchi, T., Shiraishi, H., Shimizu, M. E, Yamazaki, S.E., \& Morita, M. (1995). Imposex in japonese gastropods (Neogastropoda and Mesogastropoda) : Effects of tributyltin and 
triphenyltin from antifouling paints. Marine Pollution Bulletin, 31, 402-405.

Horiguchi, T., Shiraishi, H., Shimizu, M., \& Morita, M. (1997). Effects of triphenyltin chloride and five other organotin compounds on the development of imposex in the rock shell, Thais clavigera. Environmental Pollution, 95, 85-91.

Horiguchi, T., Li, Z., Uno, S., Shimizu, M., Shiraishi, H., Morita, M., Thompson, J.A.J., \& Levings, C.D. (2003). Contamination of organotin compounds and imposex im molluscs from Vancouver, Canada. Marine Environmental Research, 57, 75-88.

Huet, M., Fioroni, P., Oehlmann, J, \& Strobem, E. (1995). Comparison of imposex response in three prosobranch species. Hydrobiologia, 309, 29-35.

Hung, T.C; Hsu, W.K; Mang, P.J., \& Chuang, A.(2001). Organotins and imposex in the rock shell, Thais clavigera, from oyster mariculture areas in Taiwan. Environmental Pollution, $112,145-152$.

Kan-Atireklap, S., Tanabe, S.; Sanguansin, J., Tabucanon, M.S., \& Hungspreugs, M. (1997). Contamination by butyltin compounds and organochlorine residues in green mussel (Perna viridis, l.) from Thailand coastal waters. Environmental Pollution, 97, 79-89.

Langston, W. J, \& Pope, N.D. (1995). Determinants of TBT adsorption and desorption in estuarine sediments. Marine Pollution Bulletin, 31, 32-43

Laughlin, R.B., French, W., \& Guard, H.E. (1986). Accumulation of bis(tributyltin) oxide by the marine mussel Mytilus edulis. Environmental Science and Technology, 20, 884-890.

Limaverde, A., Terra, A.C., Feranandez, M. \& Wagener. A. de L.R. (2001). Compostos orgânicos de estanho (COE) em neogatrópodos afetados por imposex na Baía de Guanabaraanálise preliminar. In R. Moraes, M. Crapez, W. Pfeiffer \& A. Bainy (Eds), Efeitos de Poluentes in Organismos Marinhos (pp. 103- 118). Brazil: Rio de Janeiro (in Portuguese).

Liu, L.L., \& Suen, I.J. (1996) .Organotins promoting the development of imposex in the oyster drill Thais clavigera. Journal of Fisheries Society of Taiwan, 23,149-154.

Mathiessen, P., \& Gibbs, P.E. (1998). Critical appraisal of the evidence for tributyltin-mediated 
endocrine disruption in molluscs. Environmental Toxicology and Chemistry, 17, 37-43.

Magalhães, C.A., Struchi, P.P., \& Asbahr, M. (1997). Evidences of imposex in Stramonita haemastoma (Gastropoda : prosobranchia) population from harbor areas of the state of São Paulo. In Proceedings COLACMAR (pp. 282). Brazil: Santos (in Portuguese).

Mensink, B.P., Boon, J.P., ten Hallers-Tjabbes, C.C., van Hattun, B., \& Koeman, J.H. (1997). Bioaccumulation of organotin compounds and imposex occurrence in a marine food chain (Eastern Scheldt, The Netherlands). Environmental Technology, 18, 1235-1244.

Minchin, A., \& Davies, I.M. (1999). Effect of freezing on the length of the penis in Nucella lapilus. Journal of Environmental Monitoring, 1, 203-205.

Ribeiro, V.P. (2002). Evaluation of Stramonita haemastoma (Kool, 1987) as a biological indicator of environmental contamination due to organotin compounds. Master Dissertation Marine Biology Department, Universidade Federal Fluminense, Rio de Janeiro, 108p (in Portuguese).

Rilov, G., Gasith, A., Evans, S.M., \& Benayahu, Y. (2000). Unregulated use of TBT-based antifouling paints in Israel (Eastern Mediterranean) : High contamination and imposex levels in two species of marine gastropods. Marine Ecology Progress Series, 192, 229-238.

Rios, E., (1994). Seashells of Brazil. Fundação Universidade do Rio Grande, $2^{\text {nd }}$ edition, 368p. (in Portuguese).

Shim, J.W, Kahng, S.H, Hong, S.H, Kim, N.S, Kim, S.K., \& Shim, J.H. (2000). Imposex in the rock shell, Thais clavigera, as evidence of organotin contamination in the marine environment of Korea. Marine Environmental Research, 49, 435-451.

Spence, S.K., Hawkins, S.J., \& Santos, R.S. (1990). The mollusk Thais haemastoma - an exhibitor of imposex and potential biological indicator of tributyltin pollution. Marine Ecology, 11,147-156.

Stäb, J.A., Traas, T.P., Stroomberg, G. van Kesteren, J., Leonards, P., van Hattum, B., Brinkman, U.A.T., \& Cofino, W.P. (1996). Determination of organotin compounds in the foodweb of a 
shallow freshwater in The Netherlands. Archives of Environmental Contamination and Toxicology, 31, 319-328.

Stewart, C., De Mora, S.J., Jones, M.R.L., \& Miller, M.C. (1992). Imposex in New Zealand neogastropods. Marine Pollution Bulletin, 24, 204-209.

Stewart, C., \& Thompson, J.A.J. (1997). Vertical distribution of butyltin residues in sediments of British Columbia harbours. Environmental Technology, 18, 1195-1202.

Strand, J., \& Jacobsen, J.A. (2005). Accumulation and trophic transfer of organotins in marine food web from Danish coastal waters. The Science of the Total Environment (available in www.elsevier.com/locate/scitotenv).

Stroben, E., Schulte-Oehlmann, U., Fioroni, P., \& Oehlmann, J. (1995). A comparative method for easy assessment of coastal TBT pollution by the degree of imposex in Prosobranch species. Haliotis, 24, 1-12.

Tan, K.S. (1997). Imposex in three species of Thais from Singapore, with additional observations on T. clavigera (Küster) from Japan. Marine Pollution Bulletin, 34, 577-581. 
Table 1- Biological results of the bioassay. A = results for sampling 14 days after inoculation; B $=$ results for sampling 28 days after inoculation; $\mathrm{C}=$ final results of the bioassay after each treatment; F- healthy females; I - imposexed females; M - males; T- total number of animals; VDSI - level of VDSI in imposex females; \% - imposex frequency; D* - average dose (ng Sn / g of fresh tissue); Mort. - mortality; F-T - total number of healthy females; I -T -total number of imposexed females; \% $\mathrm{T}$ - total imposex frequency; $\mathrm{nr}$ - not retrieved.

\begin{tabular}{|c|c|c|c|c|c|c|c|c|c|c|c|c|c|c|c|c|c|c|}
\hline & \multicolumn{7}{|c|}{$A$} & & \multicolumn{4}{|c|}{$\mathrm{C}$} \\
\hline Aquaria & $\mathrm{F}$ & I & $\mathrm{M}$ & $\mathrm{T}$ & VDSI & $\%$ & $\mathrm{D}^{*}$ & $\mathrm{~F}$ & $\mathrm{I}$ & $\mathrm{M}$ & $\mathrm{T}$ & VDSI & $\%$ & $\mathrm{D}^{*}$ & Mort & F-T & $\mathrm{I}-\mathrm{T}$ & $\% \mathrm{~T}$ \\
\hline Control & 7 & 0 & 8 & 15 & 0 & 0 & 0 & 13 & 0 & 12 & 25 & 0 & 0 & 0 & 2 & 20 & 0 & 0 \\
\hline Control + ethanol & 6 & 2 & 7 & 15 & 1 & 25 & 0 & 15 & 0 & 10 & 25 & 0 & 0 & 0 & 2 & 21 & 2 & 8,7 \\
\hline TBT 1 & 3 & 3 & 9 & 15 & 1 & 50 & 5 & 9 & 3 & 12 & 24 & 1 & 25 & 5 & 3 & 12 & 6 & 33,3 \\
\hline TBT 2 & 3 & 5 & 7 & 15 & 1 & 63 & 10 & 6 & 5 & 14 & 25 & 1 & 45 & 12 & 2 & 9 & 10 & 52,6 \\
\hline TBТ 3 & 2 & 6 & 7 & 15 & 1 & 75 & 24 & 1 & 6 & 5 & 12 & 2,3 & 86 & 20 & 15 & 3 & 12 & 80,0 \\
\hline TPТ 1 & $\mathrm{nr}$ & $\mathrm{nr}$ & $\mathrm{nr}$ & - & 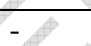 & - & - & 3 & 1 & 5 & 9 & 1 & 25 & 5 & 33 & 3 & 1 & 25,0 \\
\hline TPT 2 & $\mathrm{nr}$ & $\mathrm{nr}$ & $\mathrm{nr}$ & - & - & - & - & 2 & 3 & 3 & 8 & 1 & 60 & 8 & 34 & 2 & 3 & 60,0 \\
\hline TPT 3 & 2 & 5 & 8 & 15 & 1 & 71 & 23 & 8 & 5 & 10 & 23 & 1,4 & 38 & 28 & 4 & 10 & 10 & 50,0 \\
\hline
\end{tabular}


Table 2. Results of organotin determination ( $\mathrm{ng} \mathrm{g}^{-1} \mathrm{ww}$ as $\mathrm{Sn}$ ) in gastropods from aquaria TBT-3 and TPhP-3 of the bioassay. Inoculated doses in $\mathrm{ng} \mathrm{g}^{-1}$ ww as Sn: (a) 24.7; (b) 24.9; (c) 20.0 and (d) 20.0; (e) 22.8; (f) 23.5; (g) 28.3; (h) 25.3.

\begin{tabular}{|l|c|c|c|c|}
\hline \multicolumn{1}{|c|}{ Samplings } & \multicolumn{2}{|c|}{14 days } & \multicolumn{2}{c|}{28 days } \\
Compound & Females & Males & Females & Males \\
\cline { 2 - 5 } & & & & \\
TBT-3 & $(\mathrm{n}=8)^{\mathrm{a}}$ & $(\mathrm{n}=8)^{\mathrm{b}}$ & $(\mathrm{n}=7)^{\mathrm{c}}$ & $(\mathrm{n}=8)^{\mathrm{d}}$ \\
TBT & $5.21 \pm 0.13$ & $<\mathrm{dl}$ & $<\mathrm{dl}$ & $<\mathrm{dl}$ \\
DBT & $29.20 \pm 5.26$ & $19.77 \pm 3.61$ & $16.00 \pm 1.17$ & $22.59 \pm 2.20$ \\
MBT & $<\mathrm{dl}$ & $2.21 \pm 0.68$ & $12.35 \pm 0.49$ & $3.06 \pm 0.03$ \\
\hline TPhT-3 & $(\mathrm{n}=7)^{\mathrm{e}}$ & $(\mathrm{n}=8)^{\mathrm{f}}$ & $(\mathrm{n}=13)^{\mathrm{g}}$ & $(\mathrm{n}=10)^{\mathrm{h}}$ \\
TPhT & $16.08 \pm 0.75$ & $4.31 \pm 0.74$ & $14.14 \pm 2.03$ & $8.23 \pm 1.85$ \\
DPhT & $1.09 \pm 0.09$ & $<\mathrm{dl}$ & $0.71 \pm 0.21$ & $<\mathrm{dl}$ \\
MPhT & $<\mathrm{dl}$ & $1.14 \pm 0.67$ & $<\mathrm{dl}$ & $4.10 \pm 1.77$ \\
$(\mathrm{DBT})$ & $12.51 \pm 1.04$ & $20.86 \pm 6.12$ & $20.89 \pm 6.72$ & $23.97 \pm 3.17$ \\
\hline
\end{tabular}


Table 3. Imposex development expressed by VDSI (Vas Deferens Sequence Index*), organotin concentrations (ng g ${ }^{-1}$ ww as $\mathrm{Sn}$ ) in $\boldsymbol{S}$. haemastoma (S.h.), and organotin concentrations in the mussel P. perna (P.p.). AC stands for Arraial do Cabo, sampling site for the biassay; 1-5 refer to sampling stations in Guanabara Bay shown under Figure 1.

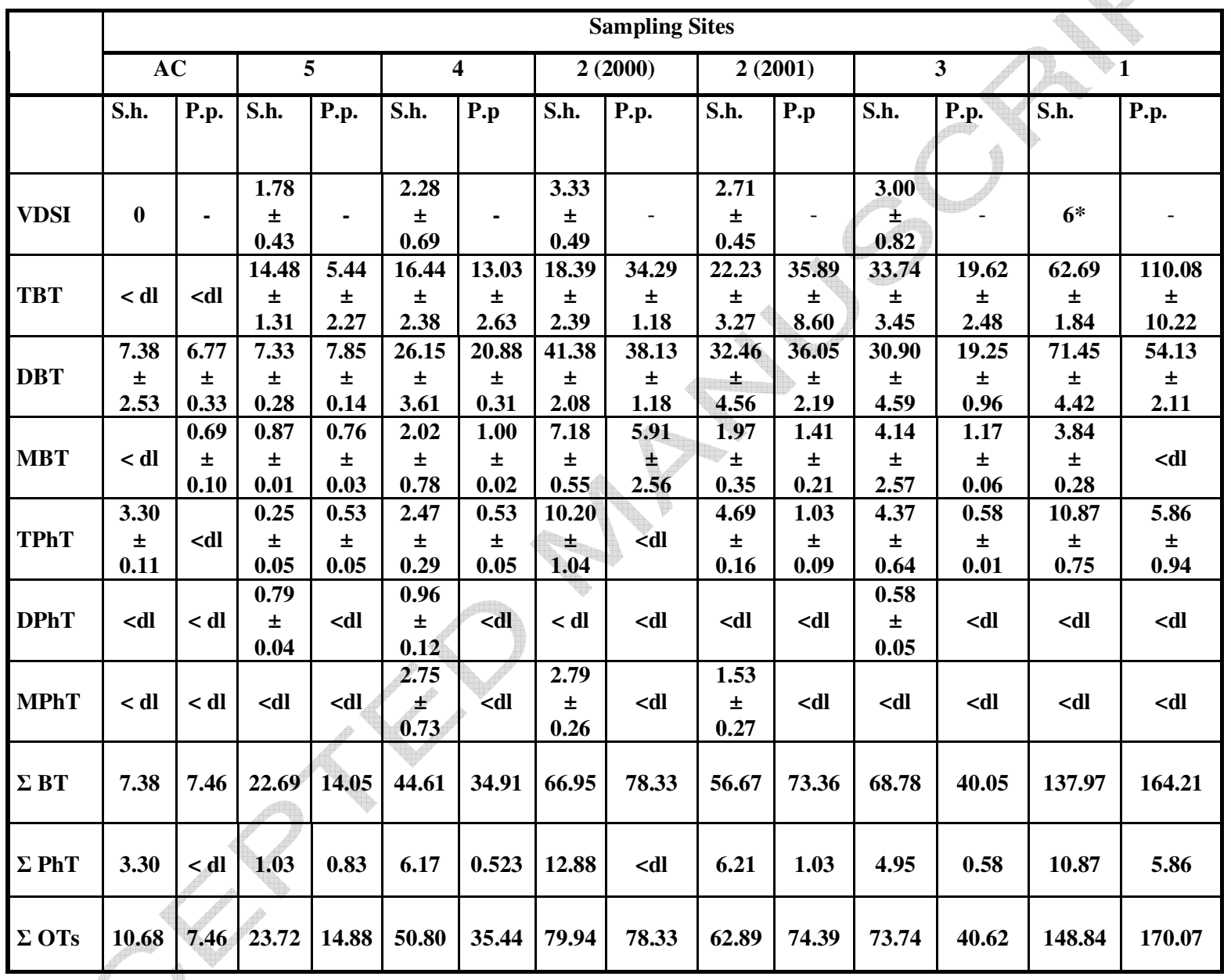


Figure 1: Sampling stations in Guanabara Bay.
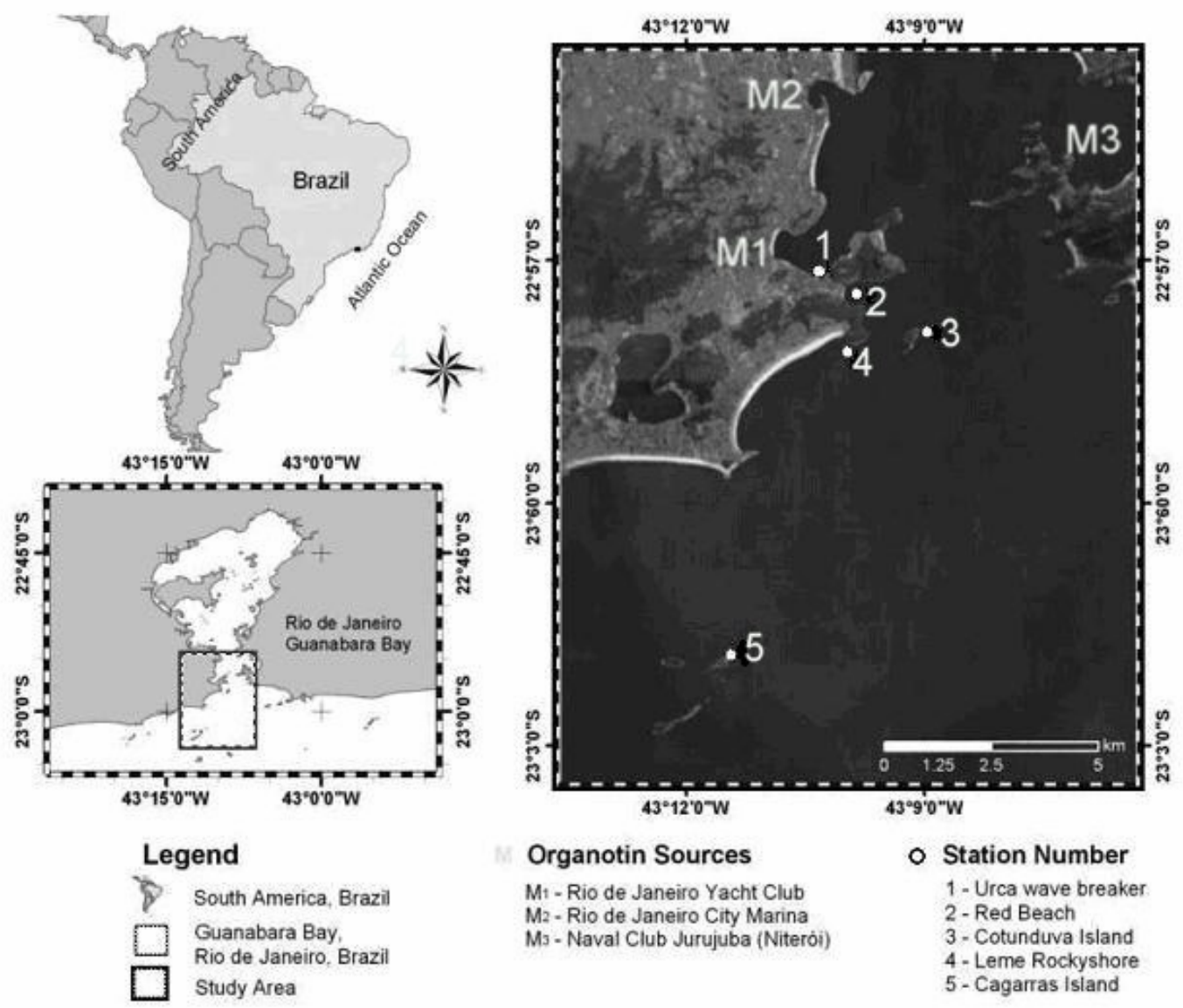
Figure 2: Imposex frequency and inoculated TBT concentrations in the different aquaria: 1 control aquarium; 2 - control aquarium + ethanol; 3 - TBT $1\left(41.5\right.$ ng. $\left.\mu \mathrm{L}^{-1}\right) ; 4$ - TBT $2(82.9$ ng. $\left.\mu \mathrm{L}^{-1}\right) ; 5-\mathrm{TBT} 3\left(165.9 \mathrm{ng} \cdot \mu \mathrm{L}^{-1}\right)$

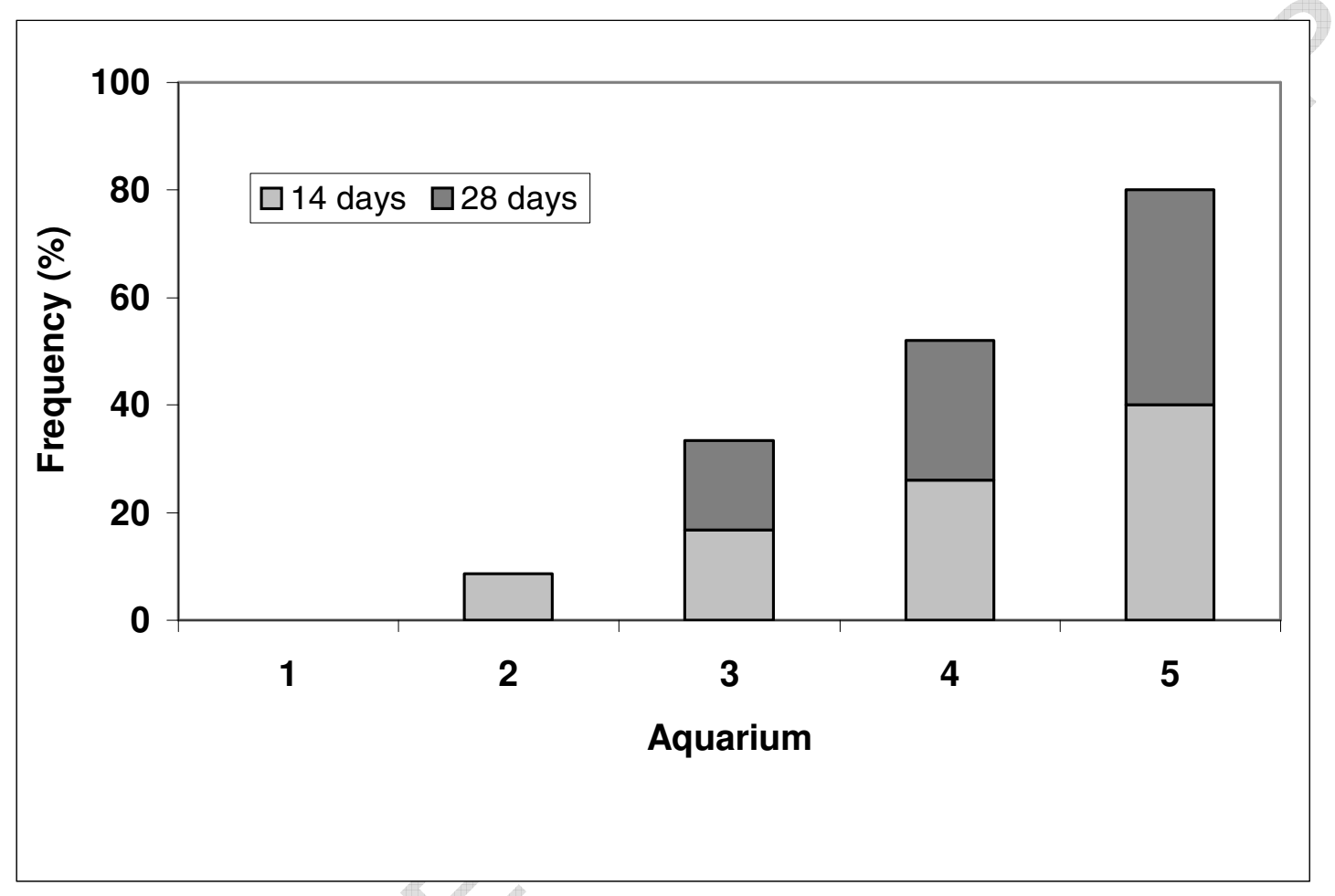


Figure 3. Calculated mass balance of organotins in the bioassay (ng $\mathrm{g}^{-1} \mathrm{ww}$ as $\mathrm{Sn}$ ). Key of abbreviations: $\mathrm{I}=$ inoculated dose of TBT or TPhT; B = DBT background concentration found in freshly harvested gastropods; $\mathrm{A}=$ total organotin body burden; $\mathrm{E}=$ excretion (calculated by difference, speciation not determined in water). OTs $=$ Total sum of butyltin and phenyltin derivatives. Codes in the abscissa: $\mathrm{B}=$ butyltin (TBT-3 aquarium), $\mathrm{M}=$ males, $\mathrm{F}=$ females, 14 and 28 days after the injection; $\mathrm{Ph}=$ phenyltin $(\mathrm{TPhT}-3$ aquarium $)$.

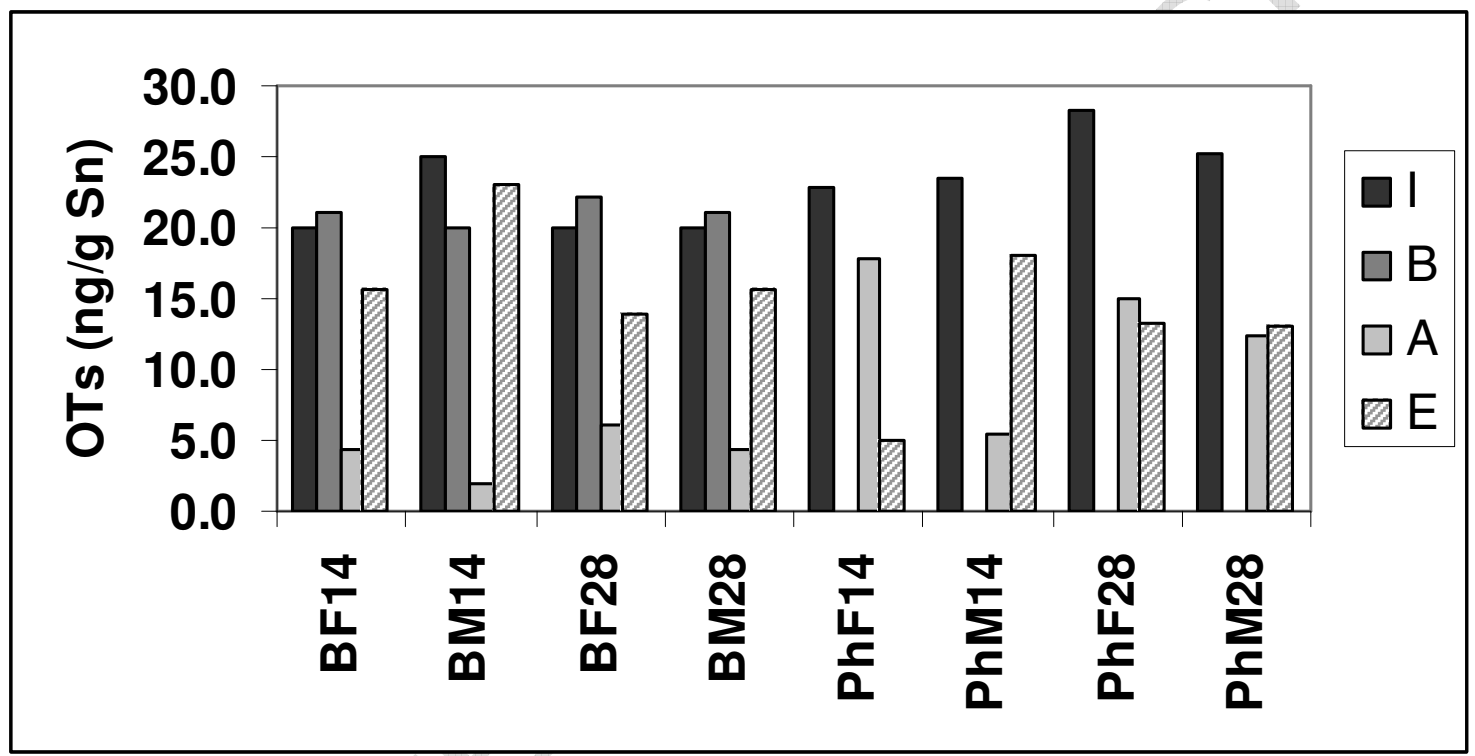


Figure 4. Correlation (linear fitting $r=0.941 ; \mathrm{p}<0.005 ;$ VDSI $=0.145+0.04$ OTs) between field data for imposex development expressed by the VDSI (Vas Deferens Sequence Index) and OTs (total organotins) concentration, $\mathrm{ng} \mathrm{g}^{-1}$ as $\mathrm{Sn}$ (black dots). Results for the bioassay (open square) and concentrations in males from Urca (open circle) were interpolated.

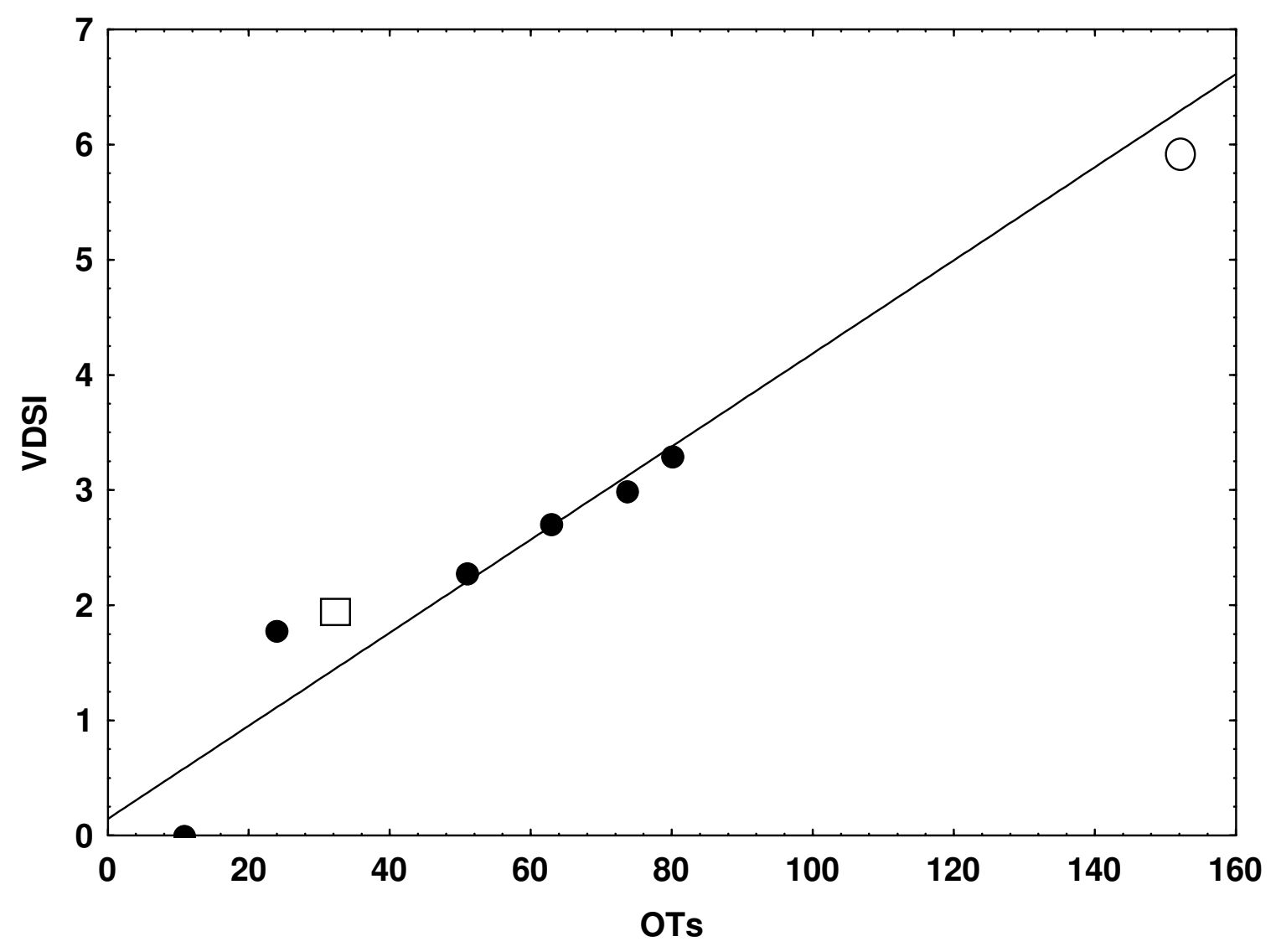

